Journal of Anatolian Environmental and Animal Sciences

(Anadolu Çevre ve Hayvancılık Bilimleri Dergisi)

DOI: https://doi.org/10.35229/jaes.672951

\title{
Adsorption of Copper (II) from Aqueous Solution by Using Carbonized Peanut Hull: Determination of the Equilibrium, Kinetic and Thermodynamic Parameters
}

\author{
Gülşad USLU ŞENEL \\ Department of Environmental Engineering, Firat University, 23100 Elazig, Turkey
}

How to cite: Uslu Șenel, G. (2020). Adsorption of Copper (II) from Aqueous Solution by Using Carbonized Peanut Hull: Determination of the Equilibrium, Kinetic and Thermodynamic Parameters. J. Anatolian Env. and Anim. Sciences, 5(2), 131-137.

Atıf yapmak için: Uslu Şenel, G. (2020). Karbonize Fıstık Kabuğu Kullanılarak Sulu Çözeltilerden Bakır (II)'nin Adsorpsiyonu: Denge, Kinetik ve Termodinamik Parametrelerin Belirlenmesi. Anadolu Çev. ve Hay. Dergisi, 5(2), 131-137.

https://orcid.org/0000-0002-5304-9436

*Corresponding author's:

Gülşad USLU ŞENEL

Department of Environmental Engineering,

Firat University, 23100 Elazig, Turkey.

凶: guslu@ firat.edu.tr

Mobile telephone : +90 (533) 7483553

Telephone : : $+90(424) 2370000 / 8403$
Abstract: In this study, the effect of temperature, $\mathrm{pH}$, initial metal concentration and adsorbent dosage on $\mathrm{Cu}(\mathrm{II})$ adsorption onto carbonized peanut hull (PHC) was investigated. Activated carbon was prepared from peanut hull. It was produced by carbonization in carbon dioxide atmosphere at $500^{\circ} \mathrm{C}$ for $1.0 \mathrm{~h}$. The maximum $\mathrm{Cu}$ (II) adsorption capacity was obtained as 168.16 $\mathrm{mg} / \mathrm{g}$ for $500 \mathrm{mg} / \mathrm{L}$ initial $\mathrm{Cu}$ (II) at $\mathrm{pH}=4.0$ and $60^{\circ} \mathrm{C}$. The Freundlich and Langmuir adsorption models were used for the mathematical description of the adsorption equilibrium. The best interpretation for the experimental data was given by the Freundlich isotherm and the maximum adsorption capacity was obtained. Batch adsorption models, based on the assumption of the pseudo-first and pseudo-second order mechanism, were applied to examine the kinetics of the adsorption. Kinetic data fitted the pseudo-second kinetic order model. Thermodynamic functions, the change of free energy $\left(\Delta \mathrm{G}^{\circ}\right)$, enthalpy $\left(\Delta \mathrm{H}^{\circ}\right)$ and entropy $\left(\Delta \mathrm{S}^{\circ}\right)$ of copper adsorption on PHC were calculated as $-23.21 \mathrm{kjmol}^{-1}$ (at $60^{\circ} \mathrm{C}$ ), $15.94 \mathrm{kjmol}^{-1}$ and $117.59 \mathrm{kjmol}^{-1} \mathrm{~K}^{-1}$, respectively, indicating the spontaneous, endothermic and the increased randomness nature of $\mathrm{Cu}^{2+}$ adsorption. The results show that adsorption of $\mathrm{Cu}$ (II) on $\mathrm{PHC}$ is an.

Keywords: Adsorption, carbonization, equilibrium, kinetic, peanut hull carbon (PHC), thermodynamic.

\section{Karbonize Fıstık Kabuğu Kullanılarak Sulu Çözeltilerden Bakır (II)'nin Adsorpsiyonu: Denge, Kinetik ve Termodinamik Parametrelerin Belirlenmesi}

*Sorumlu yazar:

Gülşad USLU ŞENEL

Firat Üniversitesi, Mühendislik Fakültesi, Çevre Mühendisliği Bölümü, 23100 Elazig,

Turkey.

$\bigotimes$ : guslu@ firat.edu.tr

Mobile telephone : +90 (533) 7483553

Telephone : +90 (424) $2370000 / 8403$
Öz: Bu çalışmada, karbonize fıstık kabuğu (PHC) üzerine $\mathrm{Cu}$ (II) adsorpsiyonuna sıcaklık, pH, başlangıç metal konsantrasyonu ve adsorban dozajın etkisi araştırılmıştır. Aktif karbon fistık kabuğundan hazırlanmıştır. PHC, karbon dioksit varlığında $500^{\circ} \mathrm{C}^{\prime} \mathrm{de} 1.0$ saat süresince karbonizasyon ile üretilmiştir. Maksimum $\mathrm{Cu}$ (II) adsorpsiyon kapasitesi, $\mathrm{pH}=4.0$ ' de $60^{\circ} \mathrm{C}$ 'de ve $500 \mathrm{mg} / \mathrm{L}$ başlangıç $\mathrm{Cu}$ (II) iyon konsantrasyonunda $168.16 \mathrm{mg} / \mathrm{g}$ olarak bulunmuştur. Adsorpsiyon dengesinin matematiksel olarak ifadesinde Freundlich ve Langmuir adsorpsiyon modelleri kullanılmıştır. Deneysel veriler için en iyi Freundlich izotermi ile verildi ve maksimum adsorpsiyon kapasitesi elde edildi. Adsorpsiyon kinetiğini incelemek için yalancı birinci ve yalancı ikinci derece düzeneğinin varsayımına dayanan bir seri adsorpsiyon modelleri uygulanmıştır. Kinetik veriler, yalancı ikinci derece kinetik düzen modeline uymuştur. PHC üzerinde bakır adsorpsiyonunun termodinamik fonksiyonları, serbest enerji değişimi $\left(\Delta \mathrm{G}^{\circ}\right)$, entalpi $\left(\Delta \mathrm{H}^{\circ}\right)$ ve entropi $\left(\Delta \mathrm{S}^{\circ}\right)$ değeleri sırasıyla $-23.21 \mathrm{kjmol}^{-1}\left(60^{\circ} \mathrm{C}^{\prime} \mathrm{de}\right), 15.94 \mathrm{kjmol}^{-1}$ ve 117.59 kjmol ${ }^{-1} \mathrm{~K}^{-1}$ olarak hesaplanmıştır. $\mathrm{Cu}^{2+}$ adsorpsiyonu endotermik bir reaksiyondur. Sonuçlar, $\mathrm{Cu}$ (II) iyonlarının adsorpsiyonunda PHC kullanımının bir alternative olacağını göstermiştir.

Anahtar kelimeler: Adsorpsiyon, denge, fistık kabuğu karbonu, karbonizasyon, kinetic, termodinamik. 


\section{INTRODUCTION}

The water pollution by toxic heavy metals through the discharge of the industrial waste is a world-wide environment problem (Jiang et al., 2009). Heavy metal ions such as cobalt, copper, nickel, chromium and zinc are detected in the waste streams from mining operations, battery manufacturing processes, the production of paints and pigments, ammunition, ceramic and glass industries tanneries, electronics, electroplating and petrochemical industries, as well as in textile mill products (Argun \& Dursun, 2008; Dursun, 2006). From the environmental risk and health hazards point of views, one of the most dangerous heavy metals is copper. Copper is heavily used metal in industries such mining and smelting, brass manufacture, electroplating industries, petroleum refining and excessive use of copper based agrichemicals mining. These industries produce much wastewater and sludge containing $\mathrm{Cu}$ (II) ions with various concentrations, which have negative effects on the water environment (Demirbaş et al., 2009). Although copper is an essential micronutrient and is required by the body in very small amounts (20-80 $\mu \mathrm{g} / \mathrm{kg}$ of body weight per day), excess exposure to copper can cause acute as well as chronic effects (WHO, 2006). Hence, the removal of copper from aques solutions is extremely important.

Heavy metal removal from aqueous solutions has been commonly carried out by several processes: chemical precipitation, solvent extraction, flotation, ion-exchange, electrolytic recovery, membrane filtration, biological process, adsorption, biosorption (Wang et al., 2007; Çetin \& Pehlivan, 2007; Giwa \& Bello, 2007). Most of these methods are extremely expensive or inefficient, especially for a large amount of solution of relatively low concentrations (Jiang et al., 2009). Adsorption is highly effective and economical method to remove heavy metal ions from aques solutions (Özçimen \& Ersoy-Meriçboyu, 2009). Among these processes, the adsorption with the selection of a suitable adsorbent can be an effective technique for the removal of heavy metals from wastewater (Bayat, 2002). The respective and widely used adsorbent material in the adsorption processes is activated carbon. Even though it has a high adsorption capacity, surface area and has a micro porous structure; it is restricted to use due to its relatively high price; high operation costs, and problems with regeneration for the industrial scale applications. This led to a search directed to developing the low-cost and locally available adsorbent materials with the maximum adsorption capacity (Sölener et al., 2008; Dursun et al., 2005; Özer et al., 2007).

The aim of this study is the evaluation of peanut hull carbon an effective, low cost, biomass adsorption media for the removal of metal ions from dilute aqueous waste streams. In order to achieve the aim of developing an effective adsorber, the parameters and mechanisms affective metal ion capture by peanut hull carbon must be identified and the physical and chemical limitations of the proposed technology assessed. A few researches in literature studied on copper binding ability onto PHC and they investigated the effect of $\mathrm{pH}$ on adsorption. However there is still lack of the studies focusing on temperature effects on the adsorption of copper (II) onto PHC. In earlier works, peanut hull carbon obtained from different methods to use as an adsorbent was studied for removing heavy metals such as copper (II) (Periasamy \& Namasivayam, 1996) and nickel (II) (Gong et al., 2005) ions and dyes (Gong et al., 2005). The present study, deals with understanding of the temperature effects on the biosorption and one of the main objective of the work is to investigate the feasibility of using PHC in the batch model for adsorption of copper (II). The sorption phenomena were expressed by the Langmuir and Freundlich adsorption models and model constants were evaluated depending on temperature. As there is no information about the kinetic analysis of the adsorption of copper (II) by PHC, the experimental data was also analyzed using the pseudo-first and pseudo second-order adsorption kinetic models and kinetic constants were calculated. An understanding of the kinetics of sorption gives useful knowledge for on-site fullscale applications. Since the evaluation of the heat change of the adsorption process is very important for reactor design, the thermodynamics of the adsorption process was also investigated.

Equilibrium modeling in a batch system: Adsorption is a well-known equilibrium separation process for wastewater treatment. Adsorption isotherms are the equilibrium relationships between the concentrations of adsorbed metal and metal in solution at a given temperature. The well-accepted adsorption isotherm models of Freundlich and Langmuir have successfully described $\mathrm{Cu}$ (II) adsorption isotherms.

The well-known expression of the Langmuir model is given by Equation (1)

$$
q_{e q}=\frac{q_{\max } K C_{e q}}{1+K C_{e q}}
$$

where $\mathrm{K}$ is the adsorption equilibrium constant including the affinity of binding sites $\left(\mathrm{L} \mathrm{mg}^{-1}\right), \mathrm{C}_{\mathrm{eq}}$ and $\mathrm{q}_{\mathrm{eq}}$ are unadsorbed metal ions in solution and adsorbed metal ions on the sorbent at equilibrium, respectively. $\mathrm{q}_{\max }$ is the maximum amount of metal ion per unit weight of adsorbent to from a complex monolayer on the surface $\left(\mathrm{mg} \mathrm{g}^{-1}\right)$ (Langmuir, 1916).

The empirical Freundlich equation based on sorption on a heterogeneous surface is given by Equation (2)

$$
q_{e q}=K_{F} C_{e q}^{1 / n}
$$

where $\mathrm{K}_{\mathrm{F}}$ and $\mathrm{n}$ are the Freundlich constants related to the adsorption capacity and adsorption intensity of the sorbent, respectively (Freundlich, 1906; Tewari, 2006). 
Kinetic Modelling: The capability of pseudo-first order and pseudo-second order kinetic models were examined in this study. The pseudo-first order equation of Lagergren is generally expressed as follows (Lagergren, 1998):

$$
\frac{d q}{d t}=k_{1}\left(q_{e q}-q\right)
$$

where $q$ is adsorbed dye quantity per gram of sorbent at any time $\left(\mathrm{mg} \mathrm{g}^{-1}\right), k_{l}$ is the rate constant of pseudofirst order sorption $\left(\mathrm{min}^{-1}\right)$. The integrated form of the differential equation becomes,

$$
\log \left(q_{e q}-q\right)=\log \left(q_{e q}\right)-\frac{k_{1}}{2,303} t
$$

The pseudo-second order kinetic rate equation is expressed as (Ho \& Mckay, 1999):

$$
\frac{d q}{d t}=k_{2}\left(q_{e q}-q\right)^{2}
$$

where $\mathrm{k}_{2}$ is the rate constant of pseudo-second order sorption $\left(\mathrm{g} \mathrm{mg}^{-1} \mathrm{~min}^{-1}\right)$. For the same boundary conditions the integrated form of Equation (5) becomes

$$
\frac{t}{q}=\frac{1}{k_{2} q_{e q}^{2}}+\frac{1}{q_{e q}} t
$$

The second order rate constant can be determined from the intercept of the linearized pseudo-second order rate equation.

Thermodynamics of adsorption: In engineering practice, entropy and Gibbs free energy factors should be considered in order to determine what processes will occur spontaneously. The Gibbs free energy change $\left(\Delta G^{\circ}\right)$ can be determined using equilibrium constant (The Langmuir constant $K_{b}$ ) (Equation 7)

$\left(\Delta G^{\circ}\right)=-R T \ln K_{b}$

where $R$ is the universal gas constant $\left(8.314 \mathrm{~J} \mathrm{~mol}^{-}\right.$ ${ }^{1} \mathrm{~K}^{-1}$ ) and $T$ is the absolute temperature $(\mathrm{K}), K_{b}$ is the equilibrium constant (The Langmuir constant) (Ho \& Mckay, 1999; Kara, 2003). The higher negative value of the Gibbs free energy reflects a more energetically favourable adsorption. The equilibrium constant can be used in the Van't Hoff equation to determine the enthalpy $\left(\Delta H^{\circ}\right)$ and entropy change of biosorption $\left(\Delta S^{\circ}\right)$ as a function of temperature.

$$
\ln K_{b}=\frac{\Delta S^{0}}{R}-\frac{\Delta H^{0}}{R T}
$$

\section{MATERIALS AND METHODS}

Preparation of peanut hull carbon (PHC): Raw peanut hull material used in this study was obtained from a local market in Elazig, Turkey. It was extensively washed with top water to remove soil and dust, sprayed with distilled water than the raw peanut hulls were prepared by air-drying to environmental equilibrium moisture in the lab on shallow trays at room temperature followed by grinding and sieve analysis. It was grounded and sieved to 50-100 mesh size $(0.34-0.15 \mathrm{~mm})$ to separate the material into discrete particle size ranges. Then, powder of peanut hull $(25 \mathrm{~g})$ was placed in a horizontal ceramic tube furnace and heated up to $500{ }^{\circ} \mathrm{C}$ at a rate of $5{ }^{\circ} \mathrm{C} / \mathrm{min}$. It was left at this temperature to thermally decompose to porous carbonaceous materials for $1 \mathrm{~h}$ and than allowed to cool to room temperature in carbon dioxide atmosphere carbon production yield from peanut hull was $\% 25$.

Physical and Chemical Characterized of Adsorbent: Characterization of the peanut hull was performed by infrared spectroscopy (IR) and by determination of the BET surface area.

Fourier transforms infrared spectroscopy (FT-IR) was used to determine the vibration frequency changes in the functional groups in the peanut hull. The spectra of $\mathrm{PH}$ were measured by on FTIR spectrometer within the range of 500$4000 \mathrm{~cm}^{-1}$ wave number. The infrared spectrum of raw $\mathrm{PH}$ and PHC were obtained with Mattson 1000 FTIR spectrometer with a pellet of powdered potassium bromide and sample.

Surface area is related to the adsorption capacity of an adsorbent. The BET surface area was determined from nitrogen isotherms using a Micromeritics Flow Sorb II-2300 Surface Area Analyzer.The measured BET surface area for PHC was $41.3 \mathrm{~m}^{2} \mathrm{~g}^{-1}$.

The BET surface area was determined from nitrogen adsorption isotherms using a Micromeritics Flow Sorb II-2300 Surface Area Analyzer. The BET surface area of PHC was measured as $41.3 \mathrm{~m}^{2} \mathrm{~g}^{-1}$. The infrared spectrum of raw peanut hull and PHC were obtained with a Mattson 1000 FTIR spectrometer with a pellet of powdered potassium bromide and sample.

Chemicals: Metal ion solution was prepared by dissolving $1.0 \mathrm{~g} / \mathrm{L}$ of stock metal ion solution, which was obtained by dissolving a weight quantity of nitrate salts of the metal (Merck). The $\mathrm{pH}$ of the each solution was adjusted to the required value with dilute of concentrated $\mathrm{HNO}_{3}$ and $\mathrm{NaOH}$ solutions before mixing with the PHC. While there was no significant changes observed on $\mathrm{pH}$ in the equilibrium, the uptake $\mathrm{pH}$ was assumed constant during the experiments. The concentration of residual $\mathrm{Cu}$ (II) ions in the adsorption media were determined by using an atomic adsorption spectrophotometer (UNICAM, 929).

Adsorption studies: Copper (II) adsorption studies were performed at various initial concentrations and temperatures at constant $150 \mathrm{rpm}$ shaking glass flasks of $0.25 \mathrm{~L}$ containing of $0.1 \mathrm{~L}$ copper (II) ion solution at desired concentration including $0.5 \mathrm{~g}$ peanut hull carbon using a rotabit shaker from Selecta. Samples $5 \mathrm{~mL}$ were taken from mixture during stirring at predetermined time intervals for determining the residual $\mathrm{Cu}$ (II) ion concentration in the 
solutions. Before analysis, samples were filtered by using blue type whatman filter paper and supernatant fluid was analyzed for the remaining metal ions. All the experiments were carried out in duplicates and average values were used for further calculations. For isotherm studies, a series of flask containing $(0.1 \mathrm{~L} \mathrm{Cu}$ (II) ion solution in the range of 25-500 $\mathrm{mg} / \mathrm{L}$ were prepared. The weighed amount of $0.5 \mathrm{~g}$ PHC was added to each flask and then the mixtures were agitated at constant temperature of 20,40 and $60^{\circ} \mathrm{C}$. These experiments were carried out at a constant $\mathrm{pH}$ of 4.0 for duration $24 \mathrm{~h}$.

\section{RESULTS AND DISCUSSION}

Adsorption of copper (II) ion onto peanut hull was investigated as a function of $\mathrm{pH}$, temperature, adsorbent dosage and initial $\mathrm{Cu}$ (II) ion situation in a batch stirred reactor in this study. The kinetics and equilibrium results were given as units of adsorbed metal ion concentration at equilibrium result $\left(\mathrm{C}_{\mathrm{ad}, \mathrm{eq}}\right.$ : $\left.\mathrm{mg} / \mathrm{L}\right)$, adsorbed metal ion quantity per gram at $\mathrm{PHC}$ end unadsorbed metal ion concentration $\left(\mathrm{q}_{\mathrm{eq}}, \mathrm{g}^{-1}, \mathrm{C}_{\mathrm{eq}}, \mathrm{mg} / \mathrm{g}\right.$, respectively and adsorption yield $\left(\right.$ Ads $\left.\%=100 \times\left(\mathrm{C}_{\mathrm{o}}-\mathrm{C}_{\mathrm{eq}} / \mathrm{C}_{\mathrm{o}}\right)\right)$.

FTIR analysis: The presence of functional groups depends on the treatment procedure of the sample. Figure 1 shows the FT- IR spectrum raw material and peanut hull carbon in the spectroscopic region $4000-500 \mathrm{~cm}^{-1}$. The first peak is centered $3900 \mathrm{~cm}^{-1}$. In the spectra of the carbon materials the band of stretching $\mathrm{OH}$ vibrations (3600-3100 $\mathrm{cm}^{-1}$ ) is due to carbon surface hydroxyl and amino groups. The second broad peak at $1700 \mathrm{~cm}^{-1}$ has been assigned to the carboxyl stretching. The decreasing intensity of adsorption band of carboxyl groups at $1700 \mathrm{~cm}^{-1}$ may be attributed to the destruction of carboxyl groups during the treatment of peanut hull.

Effect of pH on Cu (II) adsorption: The $\mathrm{pH}$ of an aqueous solution is an important controlling parameter in the process of adsorption. The effect of $\mathrm{pH}$ on the adsorption capacity of copper (II) ion by PHC was evaluated within the $\mathrm{pH}$ range of 2-5.5. Removal of copper (II) ions increases with increasing solution $\mathrm{pH}$ and a maximum value was reached at an equilibrium $\mathrm{pH}$ of around $\mathrm{pH} 4$ at $100 \mathrm{mg} / \mathrm{L}$ initial copper (II) ion concentrations. Experiments were carried out up to $\mathrm{pH}$ value of 6 due to the fact that metal precipitation occurred at higher $\mathrm{pH}$ values. At very low $\mathrm{pH}$ values $(\mathrm{pH}=2-3)$, copper (II) ion adsorption was found to be very low due to competition between $\mathrm{H}_{3} \mathrm{O}^{+}$and copper (II) ions for the adsorption sites. In addition when the $\mathrm{pH}$ increases, there is a decrease in positive surface charge, which results in a lower electrostatic repulsion between the positively charged metal ion and the surface of PHC, favoring adsorption. Loading of copper (II) ions onto PHC also found to increase till $\mathrm{pH} 4$, remained constant till $\mathrm{pH} 5$ and beyond $\mathrm{pH} 6$ hydroxide precipitations took place, which in addition to adsorption contributes to the removal of metal ion.

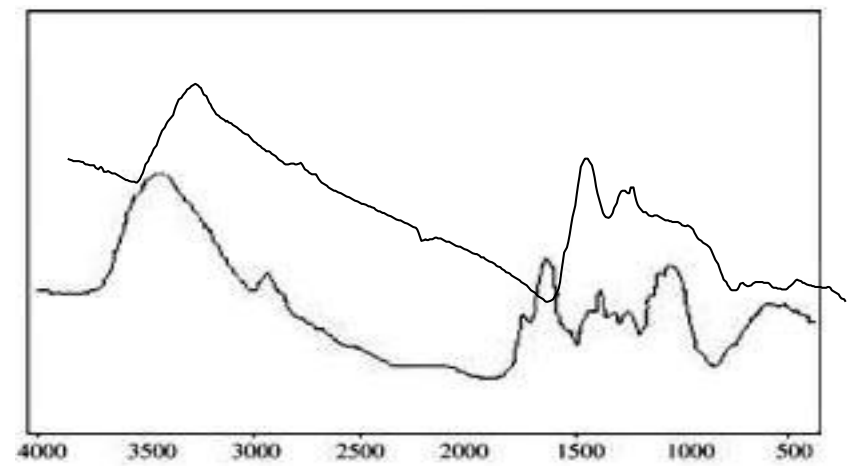

Figure 1. The IR spectrum of the peanut hull.

Effect of temperature Cu (II) adsorption: The effect of temperature $\mathrm{Cu}$ (II) uptake capacity onto PHC was studied at $100 \mathrm{mg} / \mathrm{L}$ initial metal ion concentration. The variation of equilibrium uptake with temperature was given in Table 1. Results given in Table 1 clearly showed that initial sorption of $\mathrm{Cu}$ (II) ion occurred very rapidly and reach equilibrium in $100 \mathrm{~min}$ for $100 \mathrm{mg} / \mathrm{L}$ initial $\mathrm{Cu}$ (II) ion concentrations at 20,40 and $60^{\circ} \mathrm{C}$ studied. Figure 2 shows that the adsorption of $\mathrm{Cu}$ (II) ions onto $\mathrm{PHC}$ as a function of contact time at all temperatures. Adsorption studies were carried out for $24 \mathrm{~h}$ and it was observed that, the amount of adsorbed $\mathrm{Cu}$ (II) increased linearly with time at the beginning of adsorption. A larger amount of $\mathrm{Cu}$ (II) ions were removed in the first 10 . min of contact time and the equilibrium was established in 30-60 min at the and of a rapid adsorption for all temperatures studied. After an equilibrium time of $120 \mathrm{~min}$, no more $\mathrm{Cu}$ (II) was adsorption. The optimum adsorption temperature for $\mathrm{Cu}$ (II) was determined to be $60^{\circ} \mathrm{C}$. It was shown that the removal of copper (II) ions increased with increasing temperature up to $60{ }^{\circ} \mathrm{C}$. The adsorption of $\mathrm{Cu}$ (II) was endothermic, thus extend of adsorption increased with increasing temperature. The maximum $\mathrm{Cu}$ (II) adsorption yields and desorption yields were determined as $60.20 \%, 68.44 \%$ and $83.56 \%$ and $80.73 \%, 95.52 \%$ and $99.88 \%$ at $25 \mathrm{mg} \mathrm{dm}^{-3}$ initial copper (II) ion concentration for 20,40 and $60{ }^{\circ} \mathrm{C}$, respectively (Table 1$)$.

Effect of initial metal ion concentration on $\mathrm{Cu}(\mathrm{II})$ adsorption: The effect of initial copper (II) ion concentration on the sorption capacity onto PHC was investigated at different temperatures and $\mathrm{pH}$ 4.0. The equilibrium uptake capacities of the PHC increased with increasing initial metal ion concentration up $500 \mathrm{mg} / \mathrm{L}$ because the initial $\mathrm{Cu}$ (II) concentration provides an important driving force to overcome mass transfer resistances between the adsorbent and adsorption medium. Higher sorption capacities were obtained at higher initial concentrations for copper (II) ion at all temperatures (Table 1). Increasing the metal ion 
concentration generally caused a decrease in the adsorption yield and maximum copper (II) ions adsorption yield determined as $83.56 \%$ an initial concentration $25 \mathrm{mg} / \mathrm{L}$ at 60 ${ }^{\circ} \mathrm{C}$. At higher concentrations, the ratio of initial number of metal ions to the available sites of adsorption became fewer and the saturation of the sorption sites was observed so adsorption yields decreased.

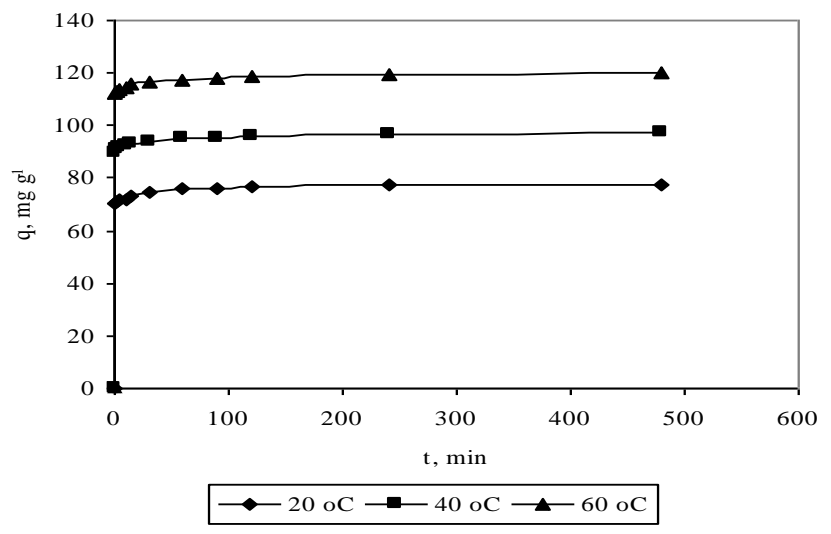

Figure 2. Copper (II) adsorption curves at given conditions.

Effect of the adsorbent dosage on the adsorption of $\boldsymbol{C u}(\boldsymbol{I I})$ : The effect of adsorbent dosage on the removal of copper (II) ion at $\mathrm{C}_{\mathrm{o}}=100 \mathrm{mg} / \mathrm{L}$ was studied. While other experimental conditions were kept constant as the adsorbent concentration was varied 0.5 to $2.5 \mathrm{~g} / \mathrm{L}$. The influence of adsorbent dosage in percentage adsorption and equilibrium uptake is depicted in Figure 3. It is clear that copper (II) ion uptake increased with increasing adsorbent dosage from 0.5 to $2.5 \mathrm{~g} / \mathrm{L}$, as the percentage of copper (II) ions removal yield decreased from 60.09 to $34.16 \%$, as the number of binding sites would be increased, but the adsorption of copper (II) ion per unit weight of adsorbent decreased from 120.18 to $68.32 \mathrm{mg} / \mathrm{g}$ of adsorbent. This is because of the availability of more and more binding sites for complexation of copper (II) ions. Adsorption sites remain unsaturated during the adsorption reaction. This is due to the fact that as the dosage of adsorbent is increased, there is less commensurate increase in adsorption resulting from the lower adsorptive capacity utilization of the adsorbent. The decrease in adsorption capacity can be explained with the reduction in the effective surface area.

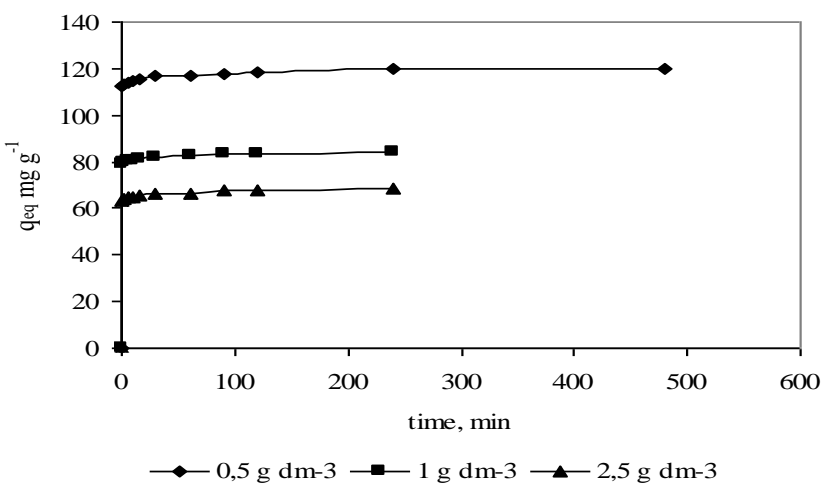

Figure 3. Influence of adsorbent dosage in adsorption yield and equilibrium uptake $\left(\mathrm{C}_{\mathrm{o}}=100 \mathrm{mg} \mathrm{L}^{-1}, \mathrm{pH}=4.0, \mathrm{~T}=60^{\circ} \mathrm{C}, \mathrm{X}: 0.5 \mathrm{~g}\right.$ $\mathrm{L}^{-1}$, agitation rate $\left.=150 \mathrm{rpm}\right)$.

Table 1. The equilibrium uptake capacities adsorption yields and desorption yields obtained at different initial concentrations and temperatures.

\begin{tabular}{|c|c|c|c|c|c|c|c|c|c|}
\hline \multirow{2}{*}{$\begin{array}{l}\mathrm{C}_{\mathrm{o}} \\
\mathrm{mg} \mathrm{dm}^{-3}\end{array}$} & \multicolumn{3}{|c|}{$20^{\circ} \mathrm{C}$} & \multicolumn{3}{|c|}{$40^{\circ} \mathrm{C}$} & \multicolumn{3}{|c|}{$60^{\circ} \mathrm{C}$} \\
\hline & $\mathrm{q}_{\mathrm{eq}}, \mathrm{mg} \mathrm{g}_{-}{ }^{1}$ & $\%$ Ad. & \% Des. & $\mathrm{q}_{\mathrm{eq}} \mathrm{mgg}{ }^{1}$ & $\%$ Ad. & \% Des. & $\mathrm{q}_{\mathrm{eq}}\left(\mathrm{mgg}^{1}\right)$ & $\%$ Ad. & $\%$ Des. \\
\hline 25 & 30.10 & 60.20 & 80.73 & 34.22 & 68.44 & 95.52 & 41.78 & 83.56 & 99.88 \\
\hline 50 & 42.92 & 42.92 & 79.68 & 48.38 & 48.38 & 95.05 & 76.24 & 76.24 & 99.45 \\
\hline 75 & 58.60 & 39.07 & 76.96 & 75.66 & 50.44 & 94.52 & 99.54 & 66.36 & 99.28 \\
\hline 100 & 77.44 & 38.72 & 75.43 & 97.18 & 48.59 & 93.89 & 120.18 & 60.09 & 99.10 \\
\hline 200 & 99.58 & 24.89 & 75.37 & 110.56 & 27.64 & 93.21 & 175.62 & 43.91 & 98.55 \\
\hline 300 & 137.12 & 22.85 & 73.23 & 149.18 & 24.86 & 92.53 & 242.18 & 40.36 & 98.15 \\
\hline 500 & 168.16 & 16.82 & 72.79 & 184.38 & 18.44 & 92.14 & 381.16 & 38.12 & 95.02 \\
\hline
\end{tabular}

Determination of equilibrium parameters: The equilibrium adsorptions isotherms are very important for the design of adsorption systems since they represent how the metal ions are partitioned between the adsorbent and liquid phases at equilibrium as a function of metal ion concentration. Various isotherm equations were well known and two different isotherms were selected in this study, which are the Langmuir and Freundlich isotherms. The linearized Langmuir and Freundlich adsorption isotherms of copper (II) ions obtained at the temperatures 20, 40 and $60^{\circ} \mathrm{C}$. The Langmuir and Freundlich adsorption constants evaluated from the isotherms and correlation coefficient are given in Table 2. As observed from the Table 2, the isotherms appeared to follow Freundlich model more closely than the Langmuir model at all the temperatures studied. The Langmuir equation is based on a monolayer adsorption by the adsorbent with the same energy of active sites. The surface of this material was expected to have nearly homogenous sites for adsorption, so a much better fit was obtained. The experimental data indicate that the amount of $\mathrm{Cu}$ (II) sorbed increased from 117.99 to $212.88 \mathrm{mg} / \mathrm{g}$ with increase in temperature from $20{ }^{\circ} \mathrm{C}$ to $60^{\circ} \mathrm{C}$. The other Langmuir constant, $\mathrm{K}$ indicates the affinity for the binding of $\mathrm{Cu}$ (II). The higher value of $\mathrm{K}$ found at $60^{\circ} \mathrm{C}$ showed strong bonding of $\mathrm{Cu}$ (II) to the $\mathrm{PHC}$ at this temperature. The Freundlich isotherm is an empirical equation employed to describe heterogeneous system. The Freundlich isotherm model exhibited a good 
fit to the experimental sorption data since the $\mathrm{r}^{2}$ values were $0.99,0.98$ and 0.99 at 20,40 and $60^{\circ} \mathrm{C}$. The Magnitude of $\mathrm{K}_{\mathrm{F}}$ and $\mathrm{n}$ of the Freundlich isotherm constants showed the tendency of $\mathrm{Cu}$ (II) uptake from the adsorption medium with high capacity of PHC especially at $60^{\circ} \mathrm{C}$. The highest $\mathrm{K}_{\mathrm{F}}$ value was determined as 21.49 at this temperature. All $\mathrm{n}$ values were found high enough for adsorption.

Table 2. Isotherms constants for $\mathrm{Cu}$ (II) ion adsorbed on PHC.

\begin{tabular}{ccccccc}
\hline \multirow{2}{*}{$\mathrm{T}\left({ }^{\circ} \mathrm{C}\right)$} & \multicolumn{3}{c}{ Langmuir Model } & \multicolumn{3}{c}{ Freundlich Model } \\
\cline { 2 - 7 } & $\mathrm{q}_{\max }$ & $\mathrm{K}$ & $\mathrm{R}^{2}$ & $\mathrm{~K}_{\mathrm{F}}$ & $\mathrm{n}$ & $\mathrm{R}^{2}$ \\
\hline 20 & 117.99 & 0.032 & 0.90 & 9.67 & 2.09 & 0.99 \\
40 & 133.19 & 0.040 & 0.86 & 14.49 & 2.33 & 0.98 \\
60 & 212.88 & 0.069 & 0.86 & 21.49 & 2.40 & 0.99 \\
\hline
\end{tabular}

Kinetic parameters of adsorption: Various kinetic models namely the lagergren's pseudo-first order, pseudo-second order and intraparticle diffusion models have been used for the validity with the experimental at adsorption process for $\mathrm{Cu}$ (II) onto PHC. With the average shaking speed of $150 \mathrm{rpm}$, it was assumed to offer no mass transfer resistance to the overall adsorption process. The values of various kinetic parameters are tabulated in Table 3 . The results showed that, the correlation coefficient for the pseudo-first order kinetic model obtained $20-60^{\circ} \mathrm{C}$ was very low and they increased with increasing temperature. The theoretical qeq,cal values found from this model did not give reasonable values especially at low temperature so pseudo-first order model could not describe the adsorption results of $\mathrm{Cu}$ (II) onto $\mathrm{PHC}$.

The values of second order adsorption rate constant, $\mathrm{k}_{2}$, were calculated. Theoretical and experimental $\mathrm{q}_{\text {eq }}$ and correlation coefficients are also given Table 3. In the view of these results, it can be said that the pseudosecond order kinetic model provided a good correlation for the adsorption of $\mathrm{Cu}$ (II) onto PHC in contrast to the pseudo-first order model.

Tablo 3. Change of the pseudo- first and second order reaction rate constants with temperature.

\begin{tabular}{|c|c|c|c|c|c|c|c|}
\hline \multirow[b]{2}{*}{$\mathrm{T},{ }^{\circ} \mathrm{C}$} & \multirow[b]{2}{*}{$\begin{array}{c}\mathrm{q}_{\text {eq,exp }} \\
\left(\mathrm{mg} \mathrm{g}^{-1}\right)\end{array}$} & \multicolumn{3}{|c|}{ First order kinetic model } & \multicolumn{3}{|c|}{ Seconder order kinetic model } \\
\hline & & $\begin{array}{c}\mathrm{k}_{1} \\
\left(\mathrm{dm}^{-3} \min ^{1}\right)\end{array}$ & $\begin{array}{c}\mathrm{q}_{\text {eq,cal }} \\
\left(\mathrm{mg} \mathrm{g}^{-1}\right)\end{array}$ & $\mathrm{R}^{2}$ & $\begin{array}{c}\mathrm{k}_{2} \\
\left(\mathrm{~g} \mathrm{mg}^{-1} \mathrm{~min}^{-1}\right)\end{array}$ & $\begin{array}{c}\mathrm{q}_{\text {eq,cal }} \\
\left(\mathrm{mg} \mathrm{g}^{-1}\right)\end{array}$ & $\mathrm{R}^{2}$ \\
\hline 40 & 97.18 & 0.015 & 9.090 & 0.61 & 0.015 & 97.20 & 0.99 \\
\hline 60 & 120.18 & 0.014 & 9.175 & 0.59 & 0.012 & 120.18 & 0.99 \\
\hline
\end{tabular}

Determination of thermodynamic parameters: Thermodynamic parameters such as free energy change $\left(\Delta \mathrm{G}^{\mathrm{o}}\right)$, enthalpy change $\left(\Delta \mathrm{H}^{\circ}\right)$, and entropy change $\left(\Delta \mathrm{S}^{\circ}\right)$ can be estimated by using equilibrium constants changing with temperature. The value of $\Delta \mathrm{G}^{\mathrm{o}}$ for the adsorption of $\mathrm{Cu}$ (II) onto PHC at different temperature $\left(20,40\right.$ and $\left.60^{\circ} \mathrm{C}\right)$ is given in Table 4. The magnitude of $\Delta \mathrm{G}^{\mathrm{o}}$ increased with the rise in temperature. Gibs free energy values for the adsorption process were obtained as $-18.55,-20.49$ and $23.21 \mathrm{kJmol}^{-1}$ for the temperatures 20,30 and $60{ }^{\circ} \mathrm{C}$, respectively. The $\mathrm{K}$ values increased with increasing temperature. The negative value of $\Delta \mathrm{G}^{\mathrm{o}}$ confirms the feasibility of the process and the spontaneous nature of adsorption of $\mathrm{Cu}$ (II) onto PHC. $\Delta \mathrm{H}^{\circ}$ for the adsorption of $\mathrm{Cu}$ (II) onto PHC was found to be $15.94 \mathrm{k} \mathrm{J} \mathrm{mol}^{-1}$ while $\Delta \mathrm{S}^{\mathrm{o}}$ was $117.59 \mathrm{k} \mathrm{J} \mathrm{mol}^{-1} \mathrm{~K}^{-1}$. The positive value of $\Delta \mathrm{H}^{\circ}$ suggested the endothermic nature of adsorption, while positive values of $\Delta S^{\circ}$ reflect the affinity of $\mathrm{Cu}$ (II) for sorbent used. In addition, positive value of $\Delta S^{\circ}$ shows the increasing randomness at the solid/liquid interface during the sorption of $\mathrm{Cu}$ (II) on selected sorbent.

Table 4. The thermodynamic constants of adsorption obtained PHC.

\begin{tabular}{ccccc}
\hline $\mathrm{T},{ }^{\circ} \mathrm{C}$ & $\mathrm{K}\left(\mathrm{dm}^{-3} \mathrm{mg}^{-1}\right)$ & $-\Delta \mathrm{G}^{\circ}\left(\mathrm{kJ} \mathrm{mol}^{-1}\right)$ & $\Delta \mathrm{H}^{\circ}\left(\mathrm{kJ} \mathrm{mol}^{-1}\right)$ & $\Delta \mathrm{S}^{\circ}\left(\mathrm{J} \mathrm{K}^{-1} \mathrm{~mol}^{-1}\right)$ \\
\hline 20 & 7.618 & 18.55 & & 117.72 \\
40 & 7.839 & 20.49 & 15.49 & 116.05 \\
60 & 8.385 & 23.21 & & 117.59 \\
\hline
\end{tabular}

\section{CONCLUSION}

PHC is an effective adsorbent for the removal of $\mathrm{Cu}$ (II) from aqueous solution. The results indicated that adsorption capacity of the adsorbent was considerably affected by initial $\mathrm{pH}$, temperature and initial $\mathrm{Cu}$ (II) concentration. The optimum $\mathrm{pH}$ value was determined to be 4.0. It was found that $\mathrm{Cu}$ (II) adsorption increased with temperature up to $60^{\circ} \mathrm{C}$ and initial $\mathrm{Cu}$ (II) ion concentration up to $500 \mathrm{mg} / \mathrm{L}$. The Langmuir and Freundlich adsorption equations were used to expiries adsorption phenomenon of the $\mathrm{Cu}$ (II). The Freundlich isotherm model at those optimum conditions best defined the equilibrium data. The PHC can be used as an effective low-cost agricultural waste adsorbent for the removal of $\mathrm{Cu}$ (II) with its adsorption capacity of $120.18 \mathrm{mg} / \mathrm{g}$ at $60^{\circ} \mathrm{C}$. The kinetics of $\mathrm{Cu}$ (II) adsorption onto PHC was examined using the pseudo-first and pseudo-second order kinetic models. The results indicated that the pseudo-second order equation provided the best correlation of the sorption data. The thermodynamic constants of adsorption were also evaluated. The negative value of $\Delta G^{o}$ confirms the spontaneous nature adsorption process. The positive value of $\Delta \mathrm{S}^{\mathrm{o}}$ showed the increased randomness at the solidsolution interface during adsorption and the positive value of $\Delta \mathrm{H}^{\mathrm{o}}$ indicated the adsorption process was endothermic. It can be concluded that the PHC would be useful for the 
economic treatment of wastewater containing $\mathrm{Cu}$ (II) to use on agricultural by-product such as peanut hull as an adsorbent.

\section{REFERENCES}

Argun, M.E. \& Dursun, S. (2008). A new approach to modification of natural adsorbent for heavy metal adsorption. Bioresearch Technology, 99, 25162527.

Bansode, R.R., Losso, J.N., Marshall, W.E., Rao, R.M. \& Portier, R.J. (2004). Pecan shell-based granular activated carbon for treatment of chemical oxygen demand (COD) in municipal wastewater. Bioresource Technology, 94, 129135.

Bayat, B. (2002). Comparative study of adsorption properties of Turkish fly ashes. I. The case of nickel(II), copper(II) and zinc(II). Journal of Hazardous Materials, 95(3), 251-273.

Cetin, S. \& Pehlivan, E. (2007). The use of fly ash as a low cost, environmentally friendly alternative to activated carbon for the removal of heavy metals from aqueous solutions. Colloids and Surfaces A: Physicochemical and Engineering Aspects. 298(1-2), 83-87.

Demirbaş, E., Dizge, N. \& Kobya, M. (2009). Adsorption kinetics and equilibrium of copper from aqueous solutions using hazelnut shell activated carbon. Chemical Eng. J, 148, 480-487.

Dursun, A.Y. (2006). A comparative study on determination of the equilibrium, kinetic and Thermodynamic parameters of adsorption of copper (II) and lead (II) ions onto pretreated Aspergillus niger. Biochem. Eng. J, 28, 187-195.

Dursun, G., Çiçek, H. \& Dursun, A.Y. (2005). Adsorption of phenol from aqueous solution by using carbonised beet pulp. Journal of Hazardous Materials, 125(1-3, 17), 175- 182.

Freundlich, H.M.F. (1906). Uberdie adsorption in lasungen. J. Phys. Chem., 57, 385-470.

Giwa, O.S. \& Bello, I.A. (2007). Removal of heavy metal from industrial wastewater using modified activated coconut shell carbon. Biochem. Engin. J., 36(2), 174-181.

Gong, R., Li, M., Yang, C., Sun, Y. \& Chen, J. (2005). Removal of cationic dyes from aqueous solution by adsorption on peanut hull. Journal of Hazardous Materials. 121(1-3), 247-250.
Gong, R., Sun, Y., Chen, J., Liu, H. \& Yang, C. (2005). Effect of chemical modification on dye adsorption capacity of peanut hull. Dyes and Pigments. 67(3), 175-181.

Ho, Y.S. \& Mckay, G. (1999). Pseudo-second order model for sorption processes, Process Biochem., 34, 451-465.

Jiang, Y., Pang, H. \& Bing, L. (2009). Removal ofg copper (II) ions from aqueous solution by modified bagasse. J of Hazardous, 164, 1-9.

Kara, M., Yüzer, H., Sabah, E. \& Çelik, M. (2003). Adsorption of cobalt from aqueous solution onto seplolite. Water Research, 37, 224-232.

Lagergren, S. (1998). Zur theorie der sogenannten adsorption geloster stoffe, Kungliga Svenska Vetenkapsakademiens, handlingar. 24, 1-39.

Langmuir, I. (1916). The constitution and fundamental properties of solids and liquids. J Am Chem Soc., 38(11), 2221-95.

Özçimen, D. \& Ersoy-Meriçboyu, A. (2009). Removal of copper from aqueoussolutions by adsorption onto chestnut shell and garpeseed activated carbons. $J$. of Hazardous. 168, 1118-1125.

Özer, D., Dursun, G. \& Özer, A. (2007). Methylene blue adsorption from aqueous solution by dehydrated peanut hull. J. of Hazard. Mater, 144, 171-179.

Periasamy, K. \& Namasivayam, C. (1996). Removal of copper (II) by adsorption onto peanut hull carbon from water and copper plating industry wastewater. Chemosphere, 32(4), 769-789.

Sölener, M., Tunali, S., Özcan, A.S., Özcan, A. \& Gedikbey, T. (2008). Adsorption characteristics of lead (II) ions onto the clay/poly (methoxyethyl)acrylamide (PMEA) composite from aqueous solutions. Desalination, 223, 308322.

Tewari, N., Vasudevan, P. \& Guha, B.K. (2005). Study on biosorption of $\mathrm{Cr}$ (VI) by Mucor hiemalis, Biochemical Eng. J. 23, 185-192.

Wang, H.J., Zhou, A.L., Peng, F., Yu, H. \& Chen, L.F. (2007). Adsorption characteristic of acidified carbon nanotubes for heavy metal $\mathrm{Pb}$ (II) in aqueous solution. Materials Science and Engineering: A. 466(1-2), 201-206.

WHO. (2006). Guidelines for Drinking-Water Quality: Incorporating First Addendum, 1, Recommendations, third ed., World Health Organization, Geneva. 